\title{
Effect of sea cucumbers Holothuria atra extract on hematological parameters and cardio enzymes in rats
}

\author{
Mohamed A. Hamed ${ }^{1}$, Emad H. Abou El-Naga ${ }^{1}$, Nagat M. Youssef ${ }^{1 *}$ \\ and Sahar S. El-Sakka \\ 1- National Institute of Oceanography \& Fishery Marine-Suez-Egypt \\ 2-s Chemistry Department, Faculty of Science, Suez University-Egypt \\ "Corresponding Author: E-mail: drnmy@ yahoo.com
}

\begin{abstract}
The present study aims to investigate the impact of the sublethal dose $\left(\mathrm{LD}_{25}\right)$ of the extract of sea cucumber Holathuria arta from Red sea on the white and red blood cells and platelet count, hemoglobin percent and cardio enzymes $(\mathrm{CK} \& \mathrm{CKmb})$ of rats after their injection (i.p.) for $1 / 2,1,6,12$ and 24 hours. The white blood cell count was significantly affected in rats injected, while platelet decreased through the first hour then reaching normal level after 24 hours, while Red blood cells count and hemoglobin weren't significantly affected. On the other hand, injection of extract of sea cucumber significantly increased serum CK and CK-MB compared to normal controls.

In conclusion, the extract toxin of sea cucumber Holothuria atra has direct effect on white blood cells count, platelet and cardio disease tests with no other effect on red blood cell count or hemoglobin.
\end{abstract}

Key words: Sea cucumber; Holathuria arta, Hematological; Cardio enzymes.

\section{INTRODUCTION}

Sea cucumbers have high commercial value and used for food and folk medicine in the communities of Asia and Middle East. Therapeutic properties and medicinal benefits of sea cucumbers can be linked to the presence of a wide array of bioactives especially triterpene glycosides (saponins), chondroitin sulfates, glycosaminoglycan (GAGs), sulfated polysaccharides, sterols (glycosides and sulfates), phenolics, cerberosides, lectins, peptides, glycoprotein, glycosphingolipids and essential fatty acids. This work is mainly designed to cover the high-value components and bioactives as well as the multiple biological and therapeutic properties of sea cucumbers with regard to exploring their potential uses for functional foods and nutraceuticals.polysaccharides (e.g., chondroitin sulfate and saponin glycosides (Sara et al., 2011).

Most of the previous studies on the sea cucumbers were are mainly on their taxonomy, ecology and biology (Clark, 1967, Hasan, 2001, 2003 and 2004). The effect of Toxen extraxcts from the Red Sea cucumbers species have received little attention. In spite of the increasing interest in pharmacology of holothurians all over the world nowadays, there is rare work done on the hematolygical \& Cardio effect of the Red Sea holothurians (Holothuria atra) on rats.

\section{Sea Cucumber Samples}

\section{MATERIALS AND METHODS}

Twenty specimens of the sea cucumbers Holothuria atra (150-200 g each) were collected from Hurghada Red Sea. 


\section{Preparation of Sea cucumber Extracts (Hot water Extraction)}

Preparation of extrct from specimens of $H$. atra was done according to Fredalina et al. (1999). Specimens were cut, ground in a blender, poured in petri dishes and dried in oven at $70^{\circ} \mathrm{C}(18-20 \mathrm{~h})$ until no change in weight was observed. The dried samples were further blended until a fine powder was produced. $12 \mathrm{~g}$ of this powder were mixed with $100 \mathrm{~mL}$ dist. Water and shked, then centrifuged at $3000 \mathrm{rpm}$ for 20 minutes and the supernatant was separated and preserved at $4^{\circ} \mathrm{C}$. The residue was further extracted (x2) using 40 and $20 \mathrm{~mL}$ of PBS, respectively. The supernatants were combined in a round-bottom flask, then freeze-dried at $50^{\circ} \mathrm{C}$ to produce a powder-like extract. Preparation was taken place at the Chemistry Laboratory, National Institute of Oceanography and Fisheries (NIOF), Suez and Aqaba Gulfs branch).

\section{Experimental Animals: \\ Swiss albino Rats}

Adult female Swiss albino rats weighing 150-200 g were housed in steel mesh cages (5 rats/ cage) in the animal house of NIOF, Suez and Aqaba Gulfs branch and feed a commercial pellet diet and drank tap water for week before starting the experiment. The animals were divided into two groups:

Group I: Normal Control (NC): Eight normal healthy rats, each received a single i.p injection of $0.25 \mathrm{~mL}$ saline and remained intact serving as normal control.

Group II: $\left(\mathbf{L D}_{\mathbf{2 5}}\right)$ : This group contained 50 normal healthy rats, each received a single i.p $\mathrm{LD}_{25}$ $(1.55 \mathrm{mg} / \mathrm{Kg}$ body weight) of the crude toxin dissolved in $0.25 \mathrm{~mL}$ saline. This dose was previously estimated by Hamed et al. (2017) for Holuthria atra.

Treated rats were divided into sacrificed by decapitation after 1/2, 1, 6, 12 and 24 hours of the injection.

\section{Hematological assays}

Hematological investigation included white blood cells count (WBCs), Red blood cells count (RBCs), Haemoglobin content $(\mathrm{Hb})$ and Blood platlets count (PLT). These were measured automatically by cell counter (ADIVA 60-ct-system, a fully automated hematology analyzer, Bayer Health Care, Germany).

\section{Cardio enzymes tests:}

The level of serum Creatine kinase $(\mathrm{CK}) \& \mathrm{CKmb}$ concentration were determinate by Automated Systems by (Bio systems analyzer A25) method of IFCC (using commercial available specific kits (Spain; Biosystems S.A.).

\section{Statistical analysis:}

The mean \pm S.E and student t-test were analysed by using statistic a ver.12 and $\mathrm{p}<$ 0.050 was accepted as a significant probability level.

\section{RESULTS AND DISCUSSION}

The blood of rat consists of a liquid phase containing a great varity of substances and cellular elements of three main varieties: leukocytes (WBCs), erythrocytes (RBCs), and platelets 


\section{Effect of sea cucumbers Holothuria atra extract on hematological parameters and cardio enzymes in rats}

(Cecil, 1997). Injection of rats with $\mathrm{LD}_{25}$ of the sea cucumber extract caused significant increase in WBC count after 30 minute and persisted up to 24 hours as show in Table (1) and Figure (1). Leukocytosis resulted from this injection was in agreement with those reported by El-Naggar et al. (1996), Haggag et al. (1999) and Mohamed (2005). Leukocytosis may be due to the increase of the absolute lymphocyte and monocyte count, as well as spleen enlargement of the injected rats which may indicate an immune modulator activity of extract (Aminin et al., 2009), or due to the inflammatory and allergic effect resulting from toxin injection. In addition, the leukocytosis may indicate an alteration in defense mechanism against the action of crude toxin of sea cucumber as reported by Abu-Amra et al. (2002a), who used tetrodotoxin. Another possible explanation for this increase of WBCs as reported by Hogan and Adams (1979) that the crude toxin may traumatize receptive tissues then causing release of leukocytosis-inducing factors which would in turn elevate the peripheral leucocytic count.

The present study revealed that the injection with $\mathrm{LD}_{25}$ of sea cucumber extract induced insignificant effect on RBCs count and hemoglobin content as show in Tables (2 \& 3) and Figures ( $2 \& 3)$. These were not in agreement with the results of Mansour et al. (1980) and AbuAmra et al. (2002b) who reported a sever decrease in Hb content and RBCs count after injection with ifferent toxins other than sea cucumber toxin such as tetrodotoxin.

Thrombocytopeni was occurred in rats after injected them with $\mathrm{LD}_{25}$ of the sea cucumber extract after 30 minutes and persisted up to 24 hours. A decrease in the blood platelets count was significant as shown in Table 4) and Figure (4). This can be due to decrease of platelets production in the bone marrow, breakdown of platelets in the blood stream or breakdown of platelets in the (liver or spleen) (Abrams, 2016). The present result was in agreement with those reported by Abu-Amra et al. (2002b) who reported a sever decrease in platelets content on injection with tetrodotoxin and snake venoms.

On the other hand, injection of hot water extract of sea cucumber significantly increased serum $\mathrm{CK}$ and $\mathrm{CK}-\mathrm{MB}$ compared to normal controls as indicated in Tables (5 \& 6) and Figures ( $5 \&$ 6). This result may be due to myocardial infarction (Armstrong et al., 2008), or may be due

to the damage of CK-rich tissue especially skeletal muscle (Hekimsoy and Oktem, 2005). The present findings were not agree with those of Jitima Suwanmala et al. (2016) who stated that i.p. injection of rats with sea cucumber extract insignificantly increased serum CK \& CK-MB. This may be related to the difference in the species of sea cucumber and also to the difference in their habitats.

In conclusion, the extract toxin of sea cucumber of Holothuria atra has direct effect on white blood cells count, platelets and Cardio enzymes with no other effect on red blood cell count or hemoglobin. 
Mohamed A. Hamed et al.

Table (1): Effect of sublethal dose $\left(\mathrm{LD}_{25}\right)$ of the extracte of sea cucumbers Holothuria atra on white blood cells count of rats.

\begin{tabular}{|l|l|l|l|l|l|c|}
\hline Groups & Number & $\begin{array}{c}\text { Mean number of } \\
\mathbf{W B C}\left(\mathbf{x 1 0}^{\mathbf{3}}\right) \mathbf{\pm} \mathbf{S E}\end{array}$ & Minimum & Maximum & \%Change & P< \\
\hline Control & 10 & $6.69 \pm 0.17$ & 6.2 & 8.00 & - & - \\
\hline $\mathbf{1} / \mathbf{2} \mathbf{h r s}$ & 10 & $8.83 \pm 0.15$ & 8.3 & 10.0 & $31.9 \%$ & 0.05 \\
\hline $\mathbf{1 ~ h r s}$ & 10 & $12.01 \pm 0.87$ & 9.1 & 16.8 & $79.5 \%$ & 0.05 \\
\hline $\mathbf{6} \mathbf{~ h r s}$ & 10 & $11.5 \pm 0.64$ & 9.4 & 16.0 & $67.9 \%$ & 0.05 \\
\hline $\mathbf{1 2} \mathbf{~ h r s}$ & 10 & $11.58 \pm 0.66$ & 8.0 & 14.2 & $73.0 \%$ & 0.05 \\
\hline $\mathbf{2 4} \mathbf{~ h r s}$ & 10 & $9.721 \pm 0.49$ & 8.2 & 13.0 & $45.3 \%$ & 0.05 \\
\hline
\end{tabular}

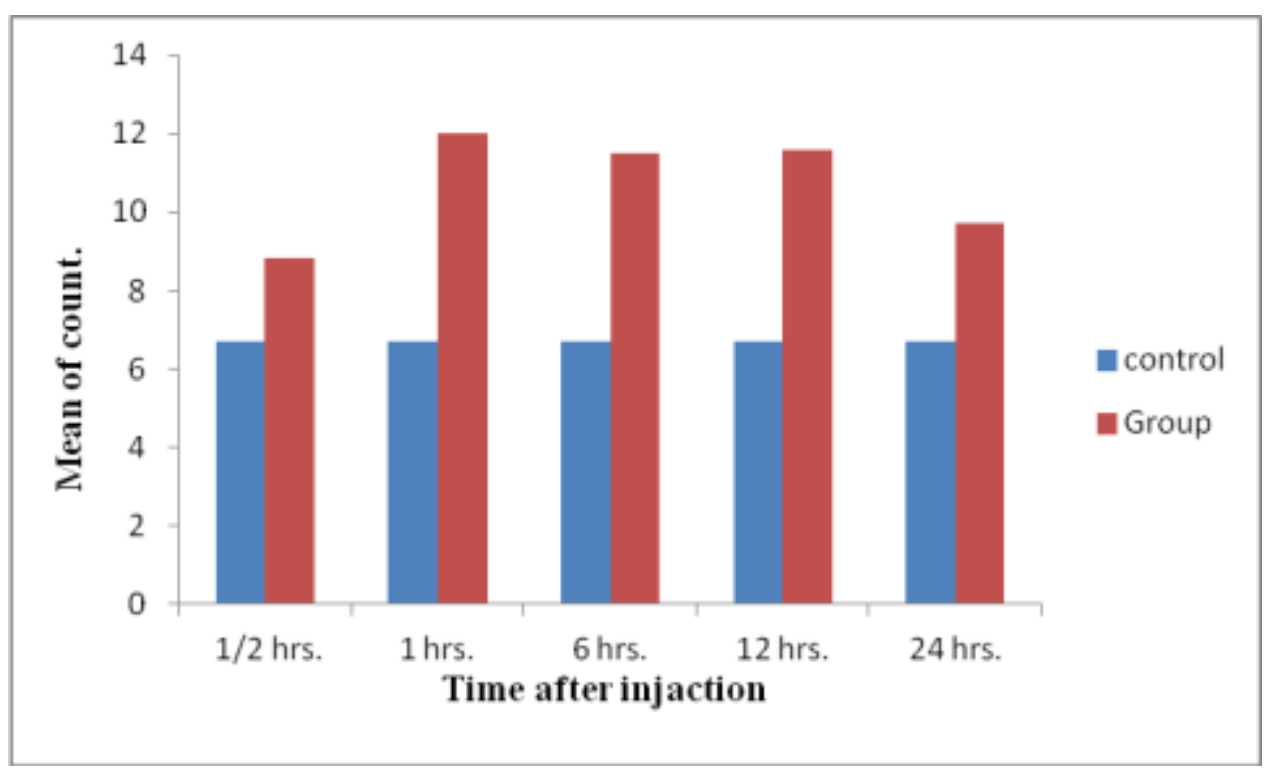

Fig. (1): Effect of sublethal dose $\left(\mathrm{LD}_{25}\right)$ of the crude toxin of sea cucumbers Holothuria atra on white blood cells count of rats

Table (2): Effect of sublethal dose (LD25) of the hot water extract of sea cucumbers Holothuria atra on Red blood cells of rats.

\begin{tabular}{|c|c|c|c|c|c|c|}
\hline Groups & Number & $\begin{array}{c}\text { Mean Number } \\
\text { of RBC }\left(\mathbf{x 1 0}^{\mathbf{6}}\right) \mathbf{\pm} \\
\mathbf{S E}\end{array}$ & Minimum & Maximum & \% Change & P< \\
\hline Control & 10 & $7.475 \pm 0.27$ & 6.15 & 8.8 & & \\
\hline $\mathbf{1} / \mathbf{h}$ hrs & 10 & $7.639 \pm 0.23$ & 6.15 & 8.8 & $2.14 \%$ & N.s \\
\hline $\mathbf{1}$ hrs & 10 & $8.357 \pm 0.68$ & 7.44 & 9.5 & $11.7 \%$ & N.S \\
\hline $\mathbf{6} \mathbf{~ h r s}$ & 10 & $7.932 \pm 0.90$ & 6.59 & 9.15 & $6.01 \%$ & N.S \\
\hline $\mathbf{1 2}$ hrs & 10 & $7.186 \pm 0.88$ & 6.25 & 8.88 & $-3.9 \%$ & N.S \\
\hline $\mathbf{2 4}$ hrs & 10 & $6.787 \pm 0.58$ & 6.0 & 7.68 & $-9.2 \%$ & N.S \\
\hline
\end{tabular}


Effect of sea cucumbers Holothuria atra extract on hematological parameters and cardio enzymes in rats

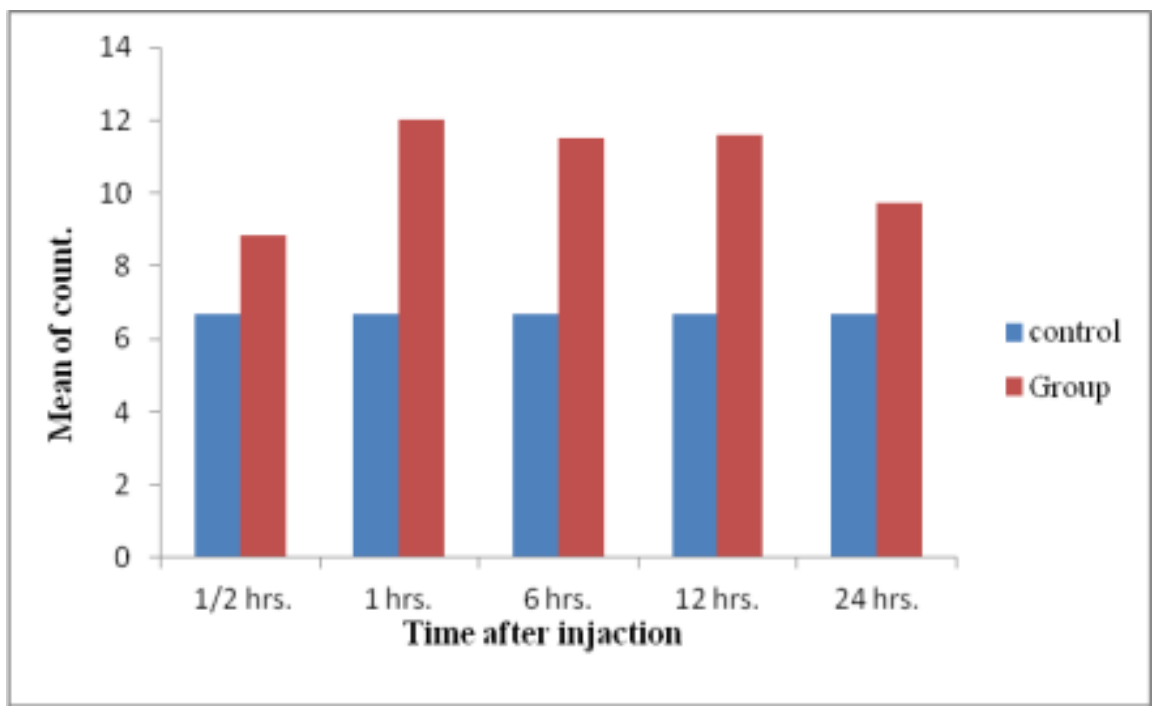

Fig. (2): Effect of sublethal dose $\left(\mathrm{LD}_{25}\right)$ of the hot water extract of sea cucumbers Holothuria atra on Red blood cells count of rats

Table (3): Effect of sublethal dose $\left(\mathrm{LD}_{25}\right)$ of the hot water extract of sea cucumbers Holothuria atra on $\mathrm{Hb} \%$ of rats

\begin{tabular}{|c|c|c|c|c|c|c|}
\hline Groups & Number & Mean Hg\% $\mathbf{\pm}$ SE & Minimum & Maximum & \% Change & P< \\
\hline Control & 10 & $7.475 \pm 0.27$ & 6.15 & 8.8 & - & - \\
\hline $\mathbf{1} / \mathbf{2}$ hrs & 10 & $7.639 \pm 0.23$ & 6.15 & 8.8 & $2.14 \%$ & N.s \\
\hline $\mathbf{1}$ hrs & 10 & $8.357 \pm 0.68$ & 7.44 & 9.5 & $11.7 \%$ & N.S \\
\hline 6 hrs & 10 & $7.932 \pm 0.90$ & 6.59 & 9.15 & $6.01 \%$ & N.S \\
\hline $\mathbf{1 2}$ hrs & 10 & $7.186 \pm 0.88$ & 6.25 & 8.88 & $-3.9 \%$ & N.S \\
\hline $\mathbf{2 4}$ hrs & 10 & $6.787 \pm 0.58$ & 6.0 & 7.68 & $-9.2 \%$ & N.S \\
\hline
\end{tabular}

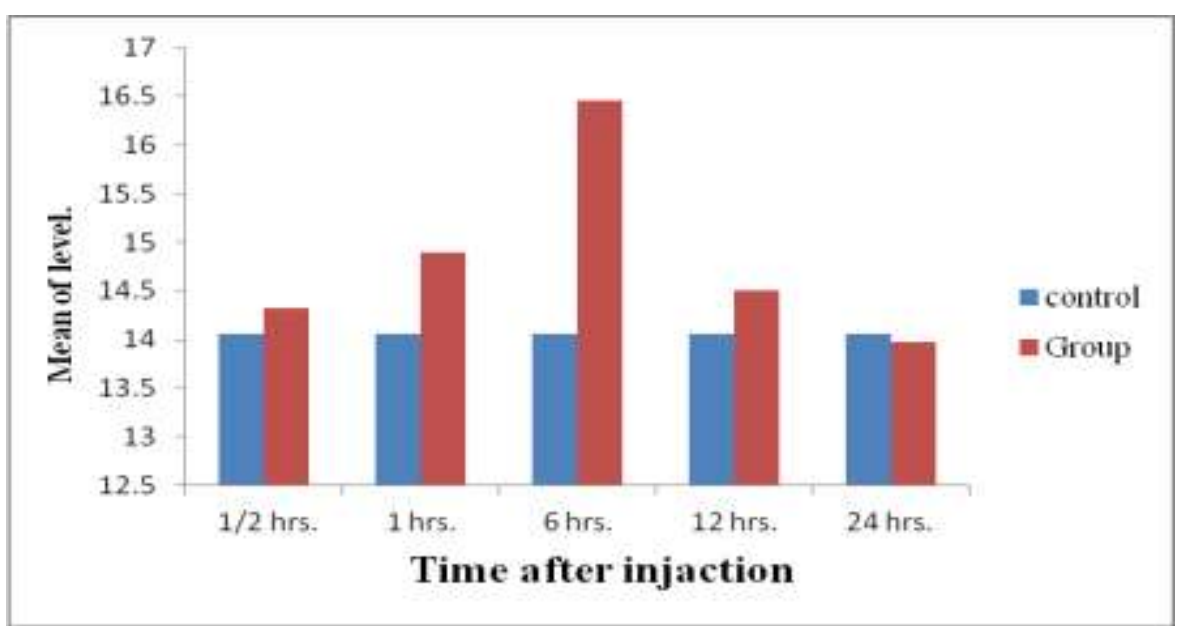

Fig. (3): Effect of sublethal dose $\left(\mathrm{LD}_{25}\right)$ of the hot water extract of sea cucumbers Holothuria atra on $\mathrm{Hb} \%$ of rats 
Mohamed A. Hamed et al.

Table (4): Effect of sublethal dose $\left(\mathrm{LD}_{25}\right)$ of hot water extract of sea cucumbers Holothuria atra on Platlets count of rats

\begin{tabular}{|c|c|c|c|c|c|c|}
\hline Groups & Number & $\begin{array}{c}\text { MeanPlatlets } \\
\text { count } \mathbf{\pm} \text { SE }\end{array}$ & Minimum & Maximum & \% Change & P< \\
\hline Control & 10 & $1243.2 \pm 32.9$ & 1133 & 1425 & - & - \\
\hline $\mathbf{1} / \mathbf{h r s}$ & 10 & $904.3 \pm 38.4$ & 722 & 1048 & -27.3 & 0.05 \\
\hline $\mathbf{1} \mathbf{~ h r s}$ & 10 & $806.4 \pm 28.9$ & 675 & 971 & -35.1 & 0.05 \\
\hline $\mathbf{6} \mathbf{~ h r s}$ & 10 & $716.5 \pm 51.1$ & 528 & 1067 & -42.4 & 0.05 \\
\hline $\mathbf{1 2}$ hrs & 10 & $399.7 \pm 29.5$ & 278 & 588 & -67.8 & 0.05 \\
\hline $\mathbf{2 4}$ hrs & 10 & $1111.1 \pm 65.8$ & 780 & 1428 & -10.6 & N.S \\
\hline
\end{tabular}

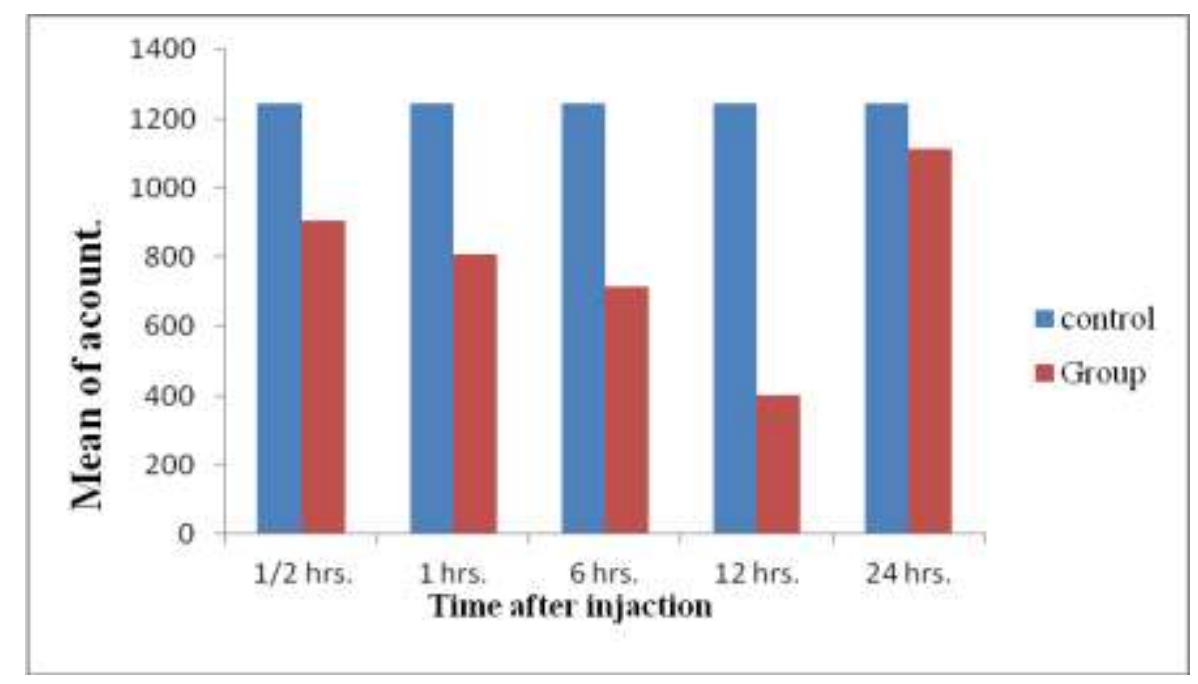

Fig (4): Effect of sublethal dose $\left(L D_{25}\right)$ of hot water extract of sea cucumbers Holothuria atra on Platlets count of rats.

Table (6): Effect of sublethal dose $\left(\mathrm{LD}_{25}\right)$ of the hot water extract of sea cucumbers Holothuria atra on serum Creatine kinase CK concentration of rats.

\begin{tabular}{|c|c|c|c|c|c|c|}
\hline Groups & Number & Mean CK $\mathbf{\pm}$ SE & Minimum & Maximum & \% Change & P< \\
\hline Control & 10 & $3986.7 \pm 286.1$ & 2579 & 5130 & & \\
\hline $\mathbf{1} / \mathbf{h}$ hrs & 10 & $10044.3 \pm 430.5$ & 7890 & 12320 & 151.9 & 0.05 \\
\hline $\mathbf{1 ~ h r s}$ & 10 & $9062.9 \pm 676.5$ & 6210 & 11928 & 127 & 0.05 \\
\hline $\mathbf{6} \mathbf{~ h r s}$ & 10 & $8689.8 \pm 675.3$ & 5013 & 11250 & 117.9 & 0.05 \\
\hline $\mathbf{1 2} \mathbf{~ h r s}$ & 10 & $7190.6 \pm 145.0$ & 6230 & 7980 & 80 & 0.05 \\
\hline $\mathbf{2 4}$ hrs & 10 & $6308.5 \pm 172.3$ & 5463 & 7290 & 58 & 0.05 \\
\hline
\end{tabular}


Effect of sea cucumbers Holothuria atra extract on hematological parameters and cardio enzymes in rats

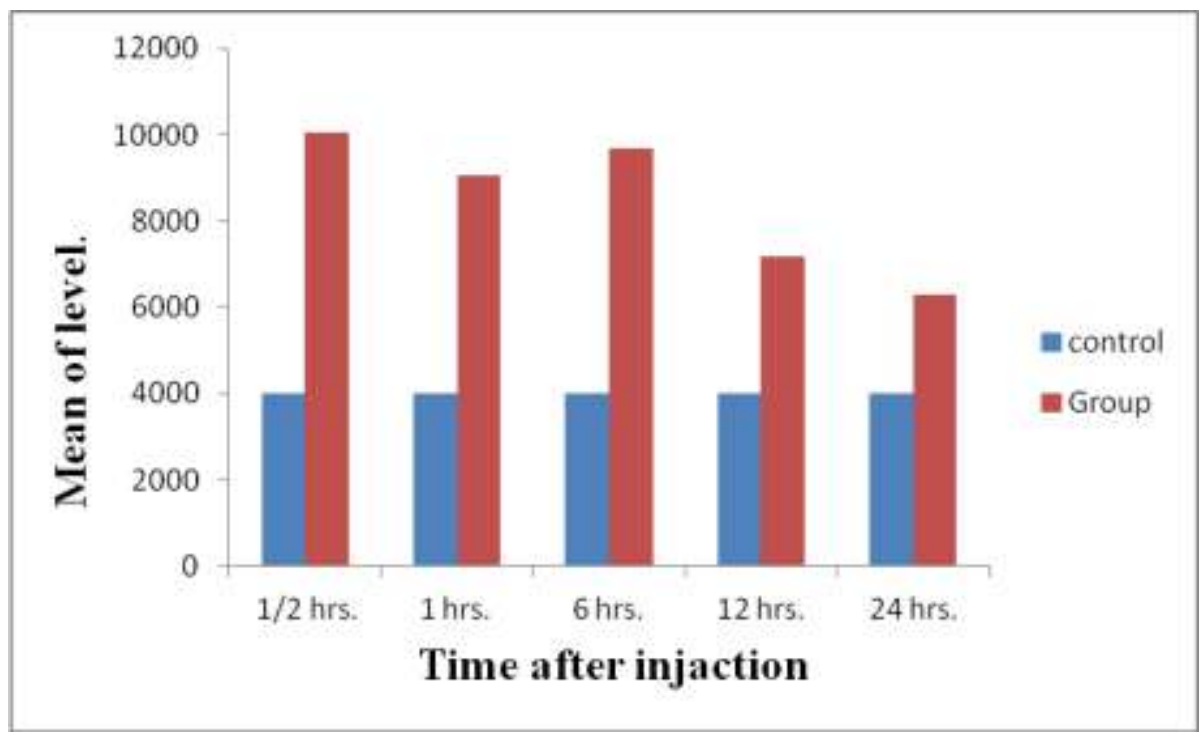

Fig. (5): Effect of sublethal dose (LD25) of the hot water extract of sea cucumbers Holothuria atra on Creatine kinase CK concentration of rats.

Table (7): Effect of sublethal dose $\left(\mathrm{LD}_{25}\right)$ of the hot water extract of sea cucumbers Holothuria atra on Creatine kinase CKmb concentration of rats.

\begin{tabular}{|c|c|c|c|c|c|c|}
\hline Groups & Number & Mean CKm \pm SE & Minimum & Maximum & \% Change & P< \\
\hline Control & 10 & $600.1 \pm 27.47$ & 429 & 730 & - & - \\
\hline $\mathbf{1} / \mathbf{h} \mathbf{h r s}$ & 10 & $2399.6 \pm 216.0$ & 1830 & 3710 & 299.8 & 0.05 \\
\hline $\mathbf{1} \mathbf{~ h r s}$ & 10 & $2476 \pm 150.9$ & 1990 & 3500 & 312.5 & 0.05 \\
\hline $\mathbf{6} \mathbf{~ h r s}$ & 10 & $4254.7 \pm 162.5$ & 3541 & 4990 & 608.9 & 0.05 \\
\hline $\mathbf{1 2} \mathbf{~ h r s}$ & 10 & $7689.8 \pm 3841$ & 2993 & 42220 & 111.4 & 0.05 \\
\hline $\mathbf{2 4} \mathbf{h r s}$ & 10 & $4280.4 \pm 195.6$ & 3090 & 5100 & 613 & 0.05 \\
\hline
\end{tabular}

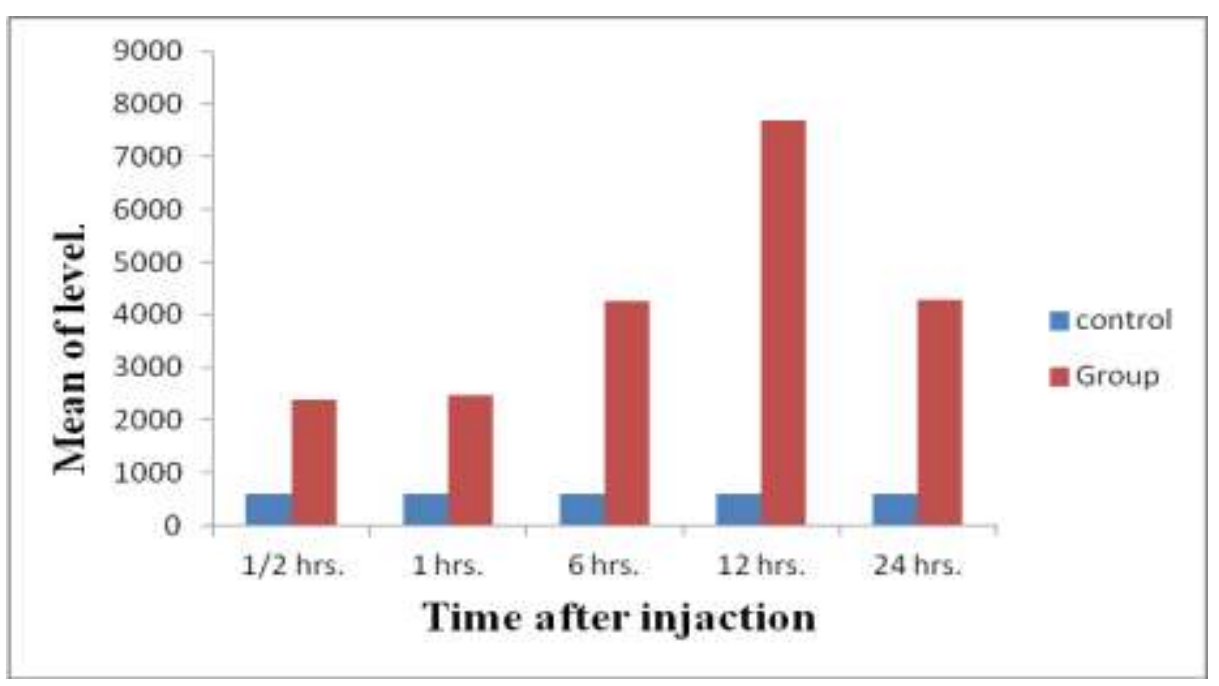

Fig. (6): Effect of sublethal dose $\left(\mathrm{LD}_{25}\right)$ of the hot water extract of sea cucumbers Holothuria atra on CK mb of rat 


\section{REFERENCE}

Abrams, C. (2016). Thrombocytopenia. In: Goldman L, Schafer AI, eds. Goldman's Cecil Medicine. 25th ed. Philadelphia, PA: Elsevier Saunders:chap 172.

Abu-Amra, E.; Abd El-Rehim, E.; Khalifa, M. H. and Abd El-Satter, M. (2002a). Influence of tetrodotoxin extracted from the overy and liver of pufferfish, Arothron hispidus, on some haemtological parameters and liver function in albino rat J. Egypt. Ger. Soc. Zool., 37 (A): $17-39$.

Abu-Amra, E.; Abd El-Rehim, E.; Khalifa, M. H. and Abd El-Satter, M. (2002b). Effect of tetrodotoxin extracted from the ovary and liver of pufferfish, Arothron hispidus, on the kidney function in albino rat. J. Egypt. Ger. Soc. Zool., 37(A): 353-367.

Althunibat, O.S.; Hashim, R.B.; Taher, M.; Daud, J.M.; Zali, B. I. and Ikeda, M. (2009). In vitro antioxidant and antiproliferative activities of three Malaysian sea cucumber species Eur. J. Sci., 37 (3): 376-387.

Aminin, D.; Koy, C. and Dmitrenok, P. (2009). Immunomodulatory effects of holothurian triterpene glycosides on mammalian splenocytes determined by mass spectrometric proteome analysis J. Proteomics, (72): 886-906.

Armstrong, W. and David, G. (2008): Pharmacology of Hemostasis and Thrombosis In Principles of the pathophysiologic basis of drug therapy.Philadelphia: Lippincott Williams \& Wilkins. p. 388.

Horder M., Elsner R., et al., Approved Recommendation of IFCC Methods for the Measurement of Catalytic Concentration of Enzymes, Part 7 IFCC Method for Creatine Kinase. J. Clin. Chem. Clin. Biochem. 29, 435, 1991.

Cecil, R.L. (1997). Cecil Essentials of medicine. $4^{\text {th }}$ edt. W.B Saunders company. London.

Clark, A.M. (1967). Echinoderms from the Red Sea. Part 2 Crinoids Ophiorids, Echinoids and Asteroids, Bull. Seafish. Res. Sta. Haifa., 41: 26-58.

El-Naggar, G.O.; Zaghloul, K.H.; Salah El-deen, M.A. and Abu-Endo, R. (1996). Histopathological and electron microscopic changes in mice treated with pufferfish toxin. J. Toxicol. Sci. , 21 (1): 1-14.

Fredalina, B.D.; Ridzwan, B. H.; Abidin, A. A.; Kaswandi, M. A.; Zaiton, H.; Zali, I.; Kittakoop, P. and jais, A.M. (1999). Fatty acid compositions in local sea cucumber, Stichopus chloronotus, for wound healing. Gen. pharmacol., 33: 337-340.

Haggag, A.M.; Marie M.A. and Zaghloul, K.H. (1999). Seasonal effects of the industrial effluent on the Nile catfish, Clarias gariepinus. J. Egypt, Ger. Soc. Zool., 28(A): 365-391.

Hamed, M.A.; Abou El-Nagat, E.; Youssed, N.M. and El-Sakka, S. S. (2017). Effect of sea cucumbers Holothuria atra extract on liver and kidney functions in rats. J. Egypt. Acad. Soc. Environ. Develop., 18 (1): 11-20

Hasan, M.H. (2001). Taxonomical and biochemical studies on some species of class holothuroidea (Echinodermata) from the Red sea. Ph.D. Thesis, Faculty of Science, Suez Canal University Ismailia, Egypt.

Hasan, M.H. (2003). Ecology and distribution patterns of the threatened holothuroid as correlated with over fishing in the Gulf of Aqaba, Northern Red Sea., Egypt. J. Egypt, Ger. Soc. Zool., 43 (D): 287-306.

Hasan, M. H. and Hasan, Y. S. (2004). Natural ecological factors and human impacts influencing the spatial distribution of holothuroids species in the Gulf of Aqaba. Egypt. J. Egypt. Ger. Soc. Zool., 43 (D): 287-306. 


\section{Effect of sea cucumbers Holothuria atra extract on hematological parameters and cardio enzymes in rats}

Hawa, I.; Zulaikah, M.; Jamaludin, M.; Zainal. A.; Kaswandi, MA. and Ridzwan, B.H. (1999). The potential of the coelomic fluid in sea cucumber as an antioxidant. Department of Biomedical Science, Faculty of Allied Health Sciences,Universiti Kebangsaan Malaysia, Jalan Raja Muda A. Aziz, 50300 K. Lumpur, Malaysia.

Hekimsoy, Z. and Oktem, I.K. (2005). Serum creatine kinase levels in overt and subclinical hypothyroidism. Endocr. Res., 31(3):171-5.

Hogan, G.R. and Adams, D.P. (1979). Lead induced leukocytosis in female mice. Arch. Toxical., 41: 295-300.

Jitima, S.; Shangyun, L.; Qingjuan, T.; Charuay, S.; Rong, Z.; Suriyan, T. and Changhu, X. (2016). comparison of antifatigue activity of five sea cucumber species in a mouse model of intense exercise. Serum creatine kinase levels in overt and subclinical hypothyroidism. Endocrine research 31 (3): 171-5.

Mansour, M.E.; Abd El-Hamid, M.E.; Ramadan, M.A. and Al-Nagdy, S.A. (1980). Histochemical studies on the protin and metabolism and the blood picture in rabbits poisoned by Arthron hispidus tetrodotoxin. Ann. Zool., 16(3): 139-148.

Reed, L.J. and Meuench, H. (1938). A simple method for estimating fifty percent end points. Am. J. Hyg., 37: 493-495.

Ridzwan, H.; Nurul, A.; Zaitunnatakin, Z.; Farah, Z.; Nurzafirah, M. and Osama, A. (2014). Toxicity effects of water extracts of Holothuria atra Jaeger in mice. Asian Pacific J. Tropical Biomedicine. Kuala Lumpur, vol 4(8):614-617.

Sara, B.; Farooq, A. and Nazamid, S. (2011). High-value components and Bioactives from sea cucumbers for functional Foods. A Review. Marine Drugs, 9(10): 1761-1805.

Zaki, M. (2005). Effcts of the crud toxin of sea cucumbers Holothuria atra on some hematological and biochemical parameters in rats Egyptian J. Natural Toxin, 2:71-86.
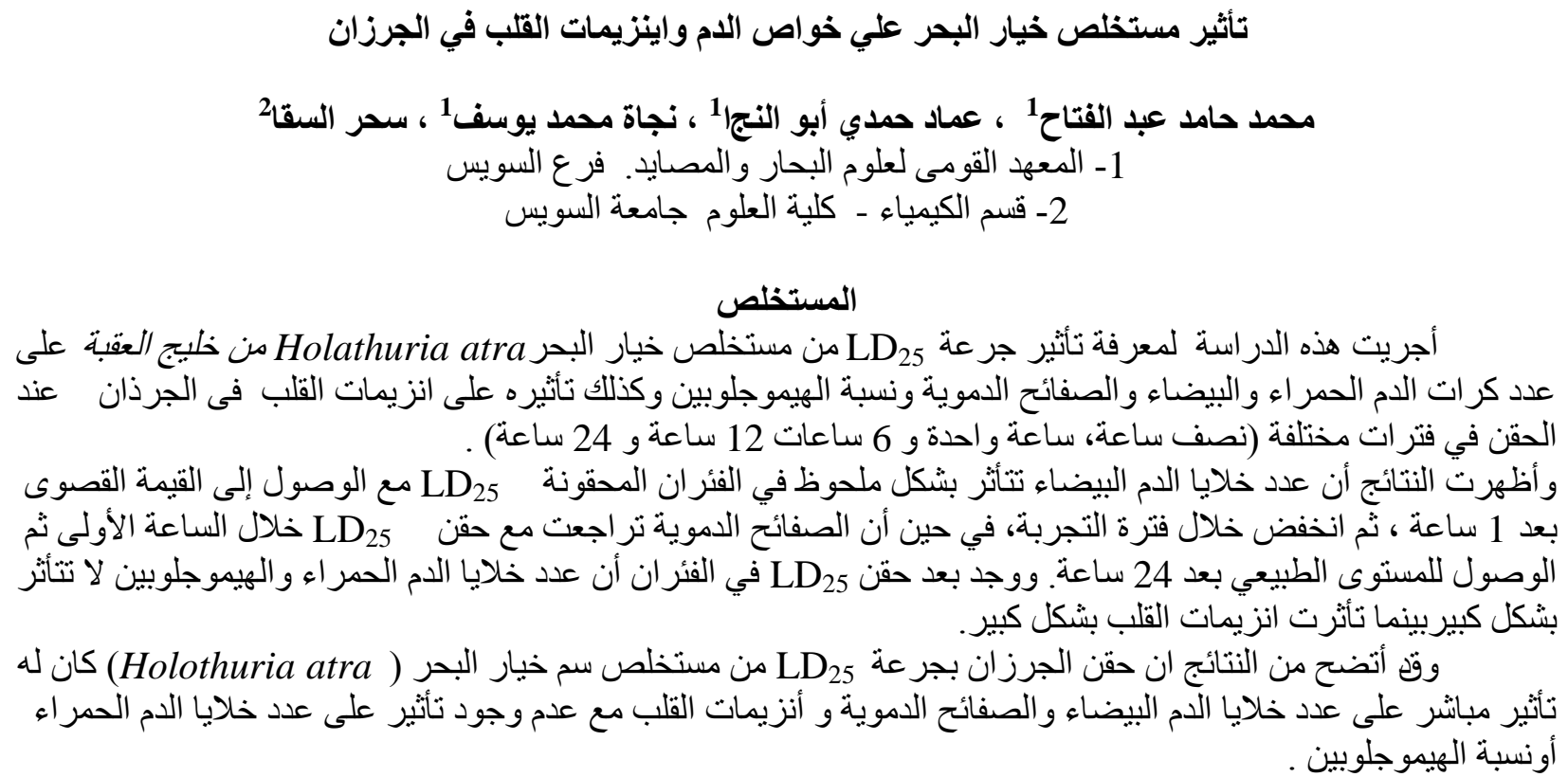